\title{
The Effects of a Professional Development Program for Technology Integrated Algebra Teaching
}

\author{
Evrim Erbilgin ${ }^{* 1}$ \& Baki Şahin ${ }^{2}$
}

* Corresponding author

E-mail: evrimerbilgin@gmail.com

1. Emirates College for Advanced

Education, Abu Dhabi, United Arab

Emirates.

2. Muğla Sıtkı Koçman University, Muğla, Turkey.

\section{Article Info}

Received: September 12, 2021

Revised: November 08, 2021

Accepted: December 17, 2021

10.46303/repam.2021.4

\section{How to cite}

Erbilgin, E., \& Şahin, B. (2021). The Effects of a Professional Development Program for Technology Integrated Algebra Teaching. Research in Educational Policy and Management, 3(2), 1-21.

https://doi.org/10.46303/repam.2021.4

\section{Copyright license}

This is an Open Access article distributed under the terms of the Creative Commons Attribution 4.0 International license (CC BY 4.0).

\section{ABSTRACT}

This study examined the development and changes in the technological pedagogical content knowledge of middle school mathematics teachers who participated in a professional development program designed to integrate technology into teaching algebra. Twenty-eight middle school teachers from 20 different schools located in a southwestern province of Turkey participated in the study. The data collection tools were the technological pedagogical content knowledge survey, reflective journals, lesson plans, and the program evaluation form. The data analysis showed that the participants' technological pedagogical content knowledge increased significantly over the course of the program. The positive effects of the professional development program seem to be related to the following components of the program: the applicability of the program activities in middle school classrooms, the program's focus on using technology in teaching algebra, the introduction of new technological tools and software related to mathematics, and the interactive nature of the program activities.

\section{KEYWORDS}

Professional development; technological pedagogical content knowledge; teacher education; teaching algebra. 


\section{INTRODUCTION}

The rapidly developing technology has influenced all aspects of our lives including learning and teaching processes in schools. We have recently witnessed this influence more significantly due to the Covid-19 breakout; many schools around the world stopped face-to-face teaching and transitioned to online education (Hove \& Dube, 2021; Subedi \& Subedi, 2020). The influences of technology on educational processes present some challenges to school teachers (RodríguezMuñiz et al., 2021). Today, teachers must teach a generation of students who were born in a digital world and experienced using a variety of digital technologies. Additionally, teachers have needed to adapt their teaching strategies for online instruction because of the pandemic. These challenges highlight the importance of professional development activities for teachers to help them use technology effectively in their lessons. This study reports on the results of a technology-focused professional development program that was designed for and used with middle school mathematics teachers.

Technology has the potential to positively influence students' mathematics performance by facilitating problem-solving and higher-order thinking (Bray \& Tangney, 2017; Tong et al., 2021). With technological tools, students and teachers have the opportunity to use the time that they spent doing tedious pencil-paper work in the past to solve problems and explore mathematical concepts in depth. For example, students can plot several functions in seconds by using a graphing calculator and examine the influence of the function parameters on the graph characteristics. This was a more difficult and time-consuming task in the past. Today, students can formulate/test hypotheses and deduce mathematical relationships through experimenting with online simulations. When used effectively, technology can support the enhancement of teaching and learning processes in mathematics classrooms (Drijvers et al., 2016; Roschelle et al., 2000).

Research studies have shown that when technological tools are used in mathematics lessons to support students' reasoning and inquisitive thinking, students' motivation and conceptual understanding increase (Drijvers et al., 2016; Raines \& Clark, 2011; Roschelle et al., 2000; Souter, 2001). In her action research, Souter (2001) compared the success, motivation, and attitude of students who learned algebra with technology to those of students who learned algebra without technology. The researcher found that the students who learned technologyassisted algebra were more motivated to learn, had a more positive attitude towards algebra, and had higher academic gains. In their literature review on the use of graphing calculators in mathematics lessons, Kastberg and Leatham (2005) reported that students who learned mathematics using a graphing calculator were more successful in practice and problem-solving questions than students who did not use graphing calculators. Similarly, the meta-analysis study conducted by Li and Ma (2010) revealed that students who learned mathematics in a computerbased learning environment were more successful than students who did not use computers to learn the same material. Tong et al. (2021) reported that technology-assisted mathematics 
instruction enhanced students' problem-solving skills and motivation to learn. The research studies pointing to the positive effects of using technology in mathematics education emphasize the effective use of technology in instruction to obtain these reported positive results.

As is the case with every educational tool, the mere use of technology in lessons will not bring success on its own. Improved learning outcomes can be obtained when technology is used to promote higher-order thinking skills, metacognition, and communication in the classrooms (Drijvers et al., 2016; Etherington, 2019; Raines \& Clark, 2011; Tong et al., 2021). Teachers have an important role in designing and delivering lessons that use technology in this manner. They can optimize the potential of technology by using activities in which students experience processes such as problem-solving, developing and testing conjectures, reflecting, inquiring, and decision-making (Ministry of National Education [MoNE], 2018; National Council of Teachers of Mathematics [NCTM], 2000). Research studies, however, point out the need to foster teachers' knowledge and practices for using technology effectively in mathematics lessons (Bray \& Tangney, 2017; Rodríguez-Muñiz et al., 2021).

\section{THEORETICAL FRAMEWORK}

Teachers need specific knowledge and skills to successfully integrate technology into their lessons (MoNE, 2018; NCTM, 2000). A theoretical framework that characterizes knowledge that teachers should master for using technology effectively is called Technological Pedagogical Content Knowledge (TPCK) and was developed by Mishra and Koehler (2006). TPCK “...emphasizes the connections, interactions, affordances, and constraints between and among content, pedagogy, and technology." (Mishra \& Koehler, 2006, p.1025). The current study used the TPCK framework to design a professional development program and assess its effects on the participating teachers' knowledge. Each knowledge domain of TPCK and their intersections are defined as follows:

- Content knowledge (CK) refers to knowledge about core concepts, theories, and procedures of a particular discipline. Teachers should have a robust understanding of the subject that they teach. In the current study, CK refers to the teachers' algebra knowledge.

- Pedagogical knowledge (PK) is a generic form of knowledge on teaching methods. It includes knowing lesson planning and delivering, developmental levels of students, assessment, and classroom management.

- Pedagogical content knowledge (PCK) includes knowing what teaching methods fit with specific content and designing teaching activities to make the content (algebra in the current study) comprehensible by students. PCK is related to the meaningful representations of the content, knowledge of what makes a concept easy or difficult, and being aware of students' conceptions and misconceptions. 
- Technology knowledge (TK) requires teachers to operate with non-digital (e.g., whiteboard) and digital (e.g., interactive board) technologies. They should be able to install and remove software and create and save documents.

- Technological content knowledge (TCK) is related to knowing which technology is suitable for teaching a particular content. In mathematics, different technological tools can be used to teach different mathematical topics.

- Technological pedagogical knowledge (TPK) refers to knowledge of technologies used in educational settings. TPK also involves knowing what affordances these technologies offer for teaching and learning processes.

- Technological pedagogical content knowledge (TPCK) requires teachers to have a robust understanding of instructional methods that use technology to teach a certain content. In the current study, TPCK refers to using specific technologies to teach and learn middle school algebra concepts.

A teacher who has robust TPCK knows and applies the pedagogical methods and techniques of teaching a subject matter using technology (Mishra \& Koehler, 2006). According to Niess (2005), a teacher's TPCK is the key factor in order for technology to promote the conceptual learning of students. For example, a mathematics teacher with a strong TPCK can choose an appropriate dynamic computer application in teaching the concept of slope and help students explore this concept by examining and connecting its multiple representations. When teachers increase their TPCK, this development can also contribute to the enhancement of teaching and learning processes in general (Martin et al., 2010; Pozdniakov \& Freiman, 2021).

With the emergence of the importance of teachers' TPCK, professional development programs aimed at increasing this type of knowledge were designed and implemented, and the effects of these programs were investigated (Mishra \& Koehler, 2006; Niess et al., 2010; Richardson, 2009). For example, Niess et al. (2010) examined how a group of primary and secondary school teachers, who were enrolled in a graduate course, used a spreadsheet program as a tool to teach science and mathematics. The TPCK levels of each teacher taking the course advanced. The researchers attributed the development of teachers' TPCK to the fact that the course activities focused on teaching a subject matter (science or mathematics) and that the teachers actively participated in the activities that required problem-solving or modeling using spreadsheets. Xie et al. (2017) taught 109 teachers from different subject areas how to evaluate digital learning contents. They found training teachers on evaluating digital content to be an effective professional development model in terms of enhancing teachers' TPCK. Richardson (2009) examined the development of TPCK of the eighth-grade mathematics teachers who participated in a 120-hour professional development program. The program focused on using technology in teaching Algebra I course. The analysis of qualitative data revealed an increase in the participating teachers' TPCK.

As the cited literature shows, researchers are designing different professional development models to enhance teachers' TPCK. Examining professional development models 
from different countries will contribute to research in this field. The professional development program examined in this study was implemented in a country (Turkey) where mathematics teachers' technology use in schools was mostly limited to preparing and reflecting slides, using an interactive board to show questions to the students, and having students watch educational videos (Bozkurt \& Cilavdaroğlu, 2011; Önal \& Çakır, 2016). Integrating technology into lesson activities in a way that allows students to explore concepts, discover ideas, and collaborate with peers to deepen their understanding was limited. One of the common suggestions of researchers working in this field is to increase and disseminate professional development programs on TPCK. Examining such programs and the TPCK changes of the teachers participating in these programs will make significant contributions to the related literature.

\section{The Professional Development Program}

The professional development program was designed based on the recommendations of the publications on how to develop effective professional development programs for teachers (Garet et al., 2001; Loucks-Horsley et al., 2010; Yoon et al., 2007). For example, programs that focused on subject matter knowledge were found to be more effective (Garet et al., 2001). Aligned with this idea, the designed program included activities that aimed to teach the algebra domain of mathematics. In particular, the focus was on using technology effectively in teaching middle school algebra. The duration of a program is also an important factor. Since the programs less than 14 hours had limited effects on teachers' knowledge and practices (Yoon et al., 2007), the designed program was planned and implemented as a 6-full day and 1-half-day program (40 hours in total). It was the maximum period that we could work with the teachers due to logistic and financial limitations. Another design element used in the program in light of the related literature was the active and collaborative participation of the teachers (Aronson et al., 2020; Loucks-Horsley et al., 2010). The professional development programs that increase professional cooperation among the teachers offer them opportunities to learn from each other and support each other's growth. Therefore, the current program included tasks that required teachers to examine the concepts or tools actively and collaboratively. The designed program included activities that engaged the participating teachers in collaborative discussions on content, pedagogy, and technology.

Content-wise, the professional development program was designed based on the TPCK framework with a focus on CK, TK, TCK, and TPCK. In each program activity, the teachers were introduced to a new technology and were engaged to use the technology to teach middle school algebra. As noted previously, the CK was middle school level algebra. In each activity, the content dimension of the activity was discussed. The TK involved learning how to use a graphing calculator, motion detector, GeoGebra-a dynamic mathematics software developed by Hohenwarter (2002), virtual manipulatives, and hands-on materials (algebra tiles and unit cubes). After learning the basic functions of these technological tools/applications (TK), the teachers completed tasks that integrated algebra with the relevant technology (TCK). To 
promote the development of the teachers' TPCK, they were asked to complete teaching activities by taking the role of a student. This approach allows the teachers to evaluate the advantages and disadvantages of the tasks from a wider perspective and to predict which processes their students might experience when they use the task in their classrooms (Boston, 2013). At the end of each activity, the teachers discussed what learning opportunities or difficulties the task might present to their students. Table 1 shows some examples of the technologies used in the program and what algebra topics and learning outcomes they were related to.

Table 1. Example Technologies Used in the Professional Development Program

\begin{tabular}{|c|c|c|}
\hline Technology & Content & Learning Outcomes \\
\hline $\begin{array}{l}\text { Algebra tiles virtual } \\
\text { manipulative } \\
\text { (https://www.nctm.org/ } \\
\text { Classroom- } \\
\text { Resources/Illuminations/ } \\
\text { Interactives/Algebra-Tiles/) }\end{array}$ & $\begin{array}{l}\text {-Linear expressions } \\
\text {-Linear equations } \\
\text {-Equality }\end{array}$ & $\begin{array}{l}\text {-Understand the role of equal sign } \\
\text { in solving linear equations. } \\
\text {-Expand and factor linear } \\
\text { expressions. } \\
\text {-Solve linear equations in one } \\
\text { variable. }\end{array}$ \\
\hline $\begin{array}{l}\text { Algebra balance scales virtual } \\
\text { manipulative } \\
\text { (http://nlvm.usu.edu/en/nav } \\
\text { / } \\
\text { frames_asid_201_g_3_t_2.ht } \\
\text { ml?open=instructions\&from= } \\
\text { category_g_3_t_2.html }\end{array}$ & $\begin{array}{l}\text {-Linear equations } \\
\text {-Equality }\end{array}$ & $\begin{array}{l}\text {-Understand the need to preserve } \\
\text { equality when solving equations. } \\
\text {-Solve linear equations in one } \\
\text { variable. }\end{array}$ \\
\hline Motion detector & $\begin{array}{l}\text {-Linear functions } \\
\text {-Quadratic functions }\end{array}$ & $\begin{array}{l}\text {-Interpret algebraic relationships } \\
\text { represented by symbols, graphs, } \\
\text { or movements. } \\
\text {-Translate among the multiple } \\
\text { representations of a linear } \\
\text { function. }\end{array}$ \\
\hline
\end{tabular}

Postcard activity (adapted from Fernandez, 2001) is described to illustrate the pedagogical approach used in the current professional development program. This activity was completed using the GeoGebra software. Before the activity, the teachers learned the basic functions of the GeoGebra program (TK) and how to plot linear functions using this program (TCK). In the activity, the teachers created digital postcards using GeoGebra. Figure 1 shows an example card. While creating the postcards, they needed to engage in mathematical reasoning and problem-solving such as finding the equation of a line, determining the intersection point of two lines, and limiting the domain of a function. For this activity, some functions of GeoGebra 
were limited so that the participants had to engage in mathematical thinking. After the participants completed creating a digital postcard, they discussed how this activity could support their students' learning (TPCK). They also discussed possible ways to revise the activity. For example, one teacher suggested differentiating the activity by requesting further criteria from the higher achieving students. Reflections on teaching activities are important for teachers to solidify their learning of content, technology, and pedagogy (Boston, 2013; Richardson, 2009).

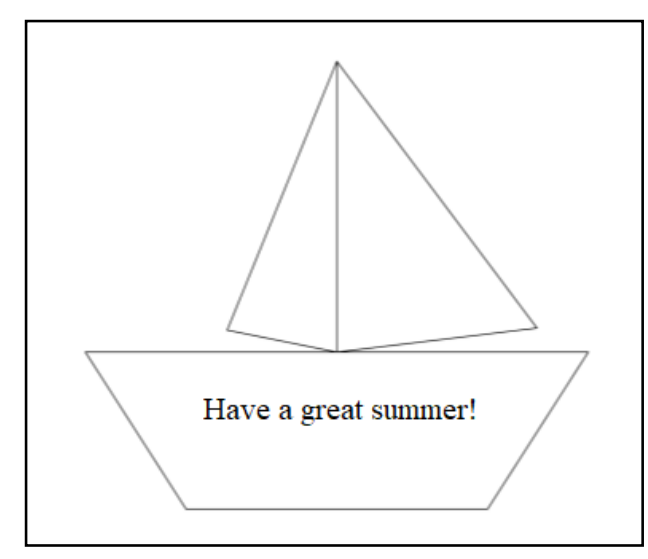

Figure 1. An Example Digital Postcard Created by Using Linear Functions

As part of the professional development program, the participating teachers were required to create two teaching materials: a lesson plan and a WebQuest. The teachers worked in groups to plan a lesson that integrated technology into teaching algebra. They were asked to implement these lessons during the next school year. The first author visited some of these lessons. The other product, WebQuest, was also designed as a group. A WebQuest is a projectbased learning activity in which students access information through the internet pages determined by the teacher. Students use Web resources to solve a problem related to real life. In the current program, each teacher group created one WebQuest and then introduced it to other groups.

\section{Purpose of the Study}

This study sought to examine the development of TPCK of 28 middle school mathematics teachers who participated in a professional development program that focused on using technology in teaching algebra. Additionally, features of the program that possibly contributed to the development of the teachers' TPCK were determined. Algebra was chosen as the subject of this research since algebra is viewed as a gateway to both advanced mathematics and technological developments (Katz, 2007). In addition, algebra fits the purpose of the study as it contains topics such as linear equations or patterns for which there is plenty of high-quality digital content that can support student learning. The research questions that guided the study are as follows: 
- Did participation in the professional development program affect the participating teachers' TPCK?

- Which elements of the professional development program were perceived by the teachers as supportive of TPCK?

\section{METHODOLOGY}

This study employed the case study method (Patton, 2002), where the case was the designed professional development program. In case studies, mixed-method of data collection and analysis can be used to analyze the case in-depth (Gürbüz \& Şahin, 2015). Accordingly, both quantitative and qualitative data were collected and analyzed in the current study to examine any changes in the TPCK of teachers participating in the professional development program. In this section, the research participants, the data sources, and the data analysis methods are presented.

\section{Participants}

In order to determine the participants of the study, all middle school mathematics teachers $(n=47)$ working in a school district located in a southwestern province of Turkey were contacted and informed about the professional development program. Of these teachers, 28 agreed to participate in the program voluntarily. The participants consisted of 13 female (46\%) and 15 male (54\%) teachers from 20 different schools. Twenty-four teachers filled out the questionnaires without missing information, and the data from these teachers were used in the dependent sample (paired) t-test analysis.

\section{Data Collection Tools}

Four different data collection tools were used in the study: the TPCK survey, reflective journals, lesson plans, and the program evaluation form. The TPCK survey was used to collect quantitative data, while the other three data collection tools were used to collect qualitative data.

The first data collection tool was the TPCK survey developed by Schmidt et al. (2009). This instrument was adapted into Turkish by Öztürk and Horzum (2011). The Turkish version was used in the current study to evaluate the TPCK of the participating teachers. The instrument consists of 47 items in seven knowledge domains (TK, CK, PK, PCK, TCK, TPK, TPCK). The participants answered each item by using a 5-point Likert scale: strongly disagree, disagree, neither agree nor disagree, agree, and strongly agree. In their instrument adaptation study, Öztürk and Horzum (2011) investigated the validity and reliability of the survey by using it with 291 teachers. The exploratory and confirmatory factor analysis results presented evidence of validity. The Cronbach alpha value was calculated to be 0.96 , an indicator of high reliability.

The second data collection tool was the group lesson plans of the participating teachers. Towards the end of the professional development program, the participants worked in groups and designed a lesson plan to use in their classes. The focus of the lesson plans was using technology in teaching algebra. These lesson plans provided information about the 
technological pedagogical content knowledge level of the participant teachers by the end of the program. The lesson plans were written using the format given in a prior curriculum (MoNE, 2009).

The third data collection tool of the study was the reflective journals of the participants. In different phases of the program, the participants answered questions in their reflective journals. For example, the participants were asked to define algebra at the beginning and at the end of the program and to write down a problem that they thought represented algebra in their journals in order to determine possible changes in their TPCK. At no point in the program, a definition for algebra was shared with the participants. The participants also wrote reflective notes on each program activity by answering open-ended questions such as "How might this activity support your students' learning? What challenges might it present?" All reflective journal questions were prepared by two mathematics educators (authors) who facilitated the program activities.

Finally, the fourth data collection tool was an evaluation form completed by the participants at the end of the program. Through this form, written information was collected about which of the program activities the participants found useful, which ones they did not find effective, and the positive and negative aspects of the program for their professional development. In addition, the participants were asked to write which elements of the program they prefer to be revised for future implementation.

\section{Data Analysis}

Aligned with the mixed-method research design, both qualitative and quantitative data analysis techniques were used in the study. The change in the participating teachers' TPCK was determined by analyzing the quantitative data obtained from the TPCK survey before and after the professional development program using the dependent sample t-test. The data collected for each sub-dimension of the survey instrument (TK, CK, PK, TCK, TPK, PCK, TPCK) were examined to find out whether there was an improvement or not.

The lesson plans written by the participating teachers were analyzed by using the Effective Technology Integration Rubric for Mathematics Lessons given in Table 2. This rubric was developed drawing on ideas in the related literature about the effective use of technology in teaching (Graham et al., 2007; NCTM, 2000; Wentworth \& Monroe, 2011). The performance criteria of the rubric are purpose of technology use, student engagement, and mathematical practices. The maximum score determined for each criterion was 2 points. 
Table 2. Effective Technology Integration Rubric for Mathematics Lessons

\begin{tabular}{|c|c|c|c|}
\hline Criteria & 0 point & 1 point & 2 points \\
\hline $\begin{array}{l}\text { Purpose of } \\
\text { Technology Use }\end{array}$ & $\begin{array}{l}\text { Technology } \\
\text { was not used } \\
\text { in the lesson or } \\
\text { was not } \\
\text { aligned with } \\
\text { the purpose of } \\
\text { the lesson. }\end{array}$ & $\begin{array}{l}\text { Technology was used } \\
\text { to introduce the topic } \\
\text { or to motivate the } \\
\text { students, but it was } \\
\text { not an essential } \\
\text { element of the lesson. } \\
\text { The topic could have } \\
\text { been taught at the } \\
\text { same level without } \\
\text { using the technology. }\end{array}$ & $\begin{array}{l}\text { Technology was used to } \\
\text { teach the concepts of } \\
\text { the } \\
\text { meaningfully, } \\
\text { supporting conceptual } \\
\text { or procedural learning. } \\
\text { Without technology, it } \\
\text { would be more difficult } \\
\text { or impossible to teach } \\
\text { the lesson. }\end{array}$ \\
\hline Student Engagement & $\begin{array}{l}\text { The teacher } \\
\text { used the } \\
\text { technology, } \\
\text { not the } \\
\text { students. }\end{array}$ & $\begin{array}{l}\text { Although the students } \\
\text { partially used the } \\
\text { technology, it was the } \\
\text { teacher who mainly } \\
\text { used it to reach the } \\
\text { purpose of the lesson. }\end{array}$ & $\begin{array}{l}\text { Students actively used } \\
\text { the technology to } \\
\text { achieve the learning } \\
\text { objectives. Technology } \\
\text { promoted students' } \\
\text { active learning. }\end{array}$ \\
\hline $\begin{array}{l}\text { Mathematical } \\
\text { Practices (Problem } \\
\text { solving, } \\
\text { communication, } \\
\text { connections, } \\
\text { representations, and } \\
\text { reasoning and proof) }\end{array}$ & $\begin{array}{l}\text { Technology did } \\
\text { not serve to } \\
\text { include the } \\
\text { mathematical } \\
\text { practices in the } \\
\text { lesson. }\end{array}$ & $\begin{array}{l}\text { Technology served to } \\
\text { include one, two, or } \\
\text { three of the } \\
\text { mathematical } \\
\text { practices in the lesson. }\end{array}$ & $\begin{array}{l}\text { Technology served to } \\
\text { include four or five of } \\
\text { the mathematical } \\
\text { practices in the lesson. }\end{array}$ \\
\hline
\end{tabular}

From the reflective journals of the participants, the definitions of algebra and the sample problems written to represent algebra were analyzed. Algebra definitions written in the journals at the beginning and end of the program were coded with the open coding technique (Strauss \& Corbin, 1990). These codes were used to understand whether there was a change in the participants' definitions of algebra (content knowledge). The codes assigned to the participants' algebra definitions were confirmed by examining the sample questions they wrote. The sample questions written by the participants were also examined to understand their pedagogical content knowledge. The most prominent mathematical practice related to meaningful learning and teaching of algebra is the use of multiple representations (NCTM, 2000). Mathematical representations involve but are not limited to, concrete materials, drawings, graphs, tables, and symbols (letters). In order to see whether there was an increase in the use of multiple representations for teaching algebra (pedagogical content knowledge), the questions written 
by the participating teachers were examined and the use of different representations was determined.

Finally, the evaluation forms completed by the participants were analyzed. The participants' opinions about the positive and negative aspects of the program were coded by using the open coding technique (Strauss \& Corbin, 1990). Then, similar codes were grouped to form themes. These themes were used to answer the second research question. In reporting the themes that emerged during open coding, frequencies and percentages were used to indicate how often the related codes and themes were observed in the qualitative data.

\section{Validity and Reliability of Qualitative Data Analysis}

Validity in qualitative research is related to presenting the researched phenomenon from the perspective of the participants as much as possible and providing the reader with the opportunity to decide whether to transfer the findings to similar situations (Lincoln \& Guba, 1985; Patton, 2002). Patton (2002) suggested that data collection and analysis processes should be done meticulously, the research context should be described to the reader in detail, and quantitative and qualitative data should be used together to ensure validity. In our study, both quantitative and qualitative data collection tools were used based on the related literature. The study context was described in detail in the theoretical framework section. In the findings section, direct quotations from the participants were presented to increase the validity of the study. Reliability in qualitative research is explained by the consistency and confirmability of the findings (Lincoln \& Guba, 1985). In this study, data and analyst triangulation were used to ensure reliability (Patton, 2002). Multiple data sources were used to understand the TPCK changes of the participating teachers. All qualitative data were analyzed by two mathematics educators (authors) collaboratively. In cases of disagreement, the researchers shared their perspectives and a consensus was reached.

\section{RESULTS}

\section{The Development of TPCK}

In this section, we present the findings related to the first research question "Did participation in the professional development program affect the participating teachers' TPCK?" In order to answer this question, we analyzed the data obtained from the TPCK survey, lesson plans, and reflective journal entries. Table 3 shows the t-test results for the TPCK survey data. According to Table 3, there is a statistically significant improvement in the participants' perception of their TPCK levels for all knowledge domains except for the pedagogical knowledge domain. These results indicate that overall, the professional development program positively influenced the participants' TPCK knowledge.

Another data source that was analyzed to understand the TPCK development of the participants was the group lesson plans. Eight lesson plans written by the teachers were analyzed using the Effective Technology Integration Rubric for Mathematics Lessons. According 
to the rubric, the lesson plans received the following scores: 5, 6, 5, 5, 6, 5, 6, 6. The maximum score a lesson plan can obtain from the rubric is 6 . The scores assigned to the lesson plans indicate that technology was an essential component of the lesson plans and was used to promote conceptual learning. Furthermore, the lesson plans assigned students an active role in using technology and required them to engage in mathematical practices. For example, one group used color chips virtual manipulative and concrete color chips to teach the addition and subtraction of integers in the context of real-life problems. Students were asked to solve problems using the chips and to conjecture rules for adding and subtracting integers. The high scores of the lesson plans show that the participating teachers were capable of planning mathematics lessons that require a high level of TPCK.

Table 3. Dependent Groups t-test Results for the Teachers' TPCK Pretest and Posttest Scores

\begin{tabular}{|c|c|c|c|c|c|c|}
\hline TPCK & Test & $n$ & $\bar{X}$ & Sd & $t$ & $p$ \\
\hline \multirow{2}{*}{ TK } & Pre & 24 & 24.6 & 5.11 & \multirow{2}{*}{3.35} & \multirow{2}{*}{$0.03 *$} \\
\hline & Post & 24 & 27.96 & 4.7 & & \\
\hline \multirow{2}{*}{ CK } & Pre & 24 & 12.67 & 3.13 & \multirow{2}{*}{2.63} & \multirow{2}{*}{$0.02 *$} \\
\hline & Post & 24 & 13.75 & 2.25 & & \\
\hline \multirow{2}{*}{ PK } & Pre & 24 & 29.5 & 4.8 & \multirow{2}{*}{1.65} & \multirow{2}{*}{0.11} \\
\hline & Post & 24 & 30.29 & 4.95 & & \\
\hline \multirow{2}{*}{ PCK } & Pre & 24 & 13.62 & 1.95 & \multirow{2}{*}{3.03} & \multirow{2}{*}{$0.01 *$} \\
\hline & Post & 24 & 15 & 2.96 & & \\
\hline \multirow{2}{*}{ TCK } & Pre & 24 & 3.83 & 0.7 & \multirow{2}{*}{4.37} & \multirow{2}{*}{$0.00 *$} \\
\hline & Post & 24 & 4.41 & 0.72 & & \\
\hline \multirow{2}{*}{ TPK } & Pre & 24 & 17.17 & 2.6 & \multirow{2}{*}{5.99} & \multirow{2}{*}{$0.00 *$} \\
\hline & Post & 24 & 20.58 & 3.45 & & \\
\hline \multirow{2}{*}{ TPCK } & Pre & 24 & 19.5 & 3.3 & \multirow{2}{*}{2.56} & \multirow{2}{*}{$0.02 *$} \\
\hline & Post & 24 & 21.1 & 3.3 & & \\
\hline
\end{tabular}

$* p<0.05$

One goal of the professional development program was to enrich the participants' perspectives about the meaning of algebra as it is part of their TPCK. To understand the change in their perception of algebra (content knowledge), algebra definitions written by the teachers at the beginning and at the end of the program were examined. Table 4 shows the themes emerged as the result of open-coding. Teachers' definitions of algebra were grouped under 3 categories: Building and solving equations, arithmetic operations, and a relationship between quantities. 
Table 4. Teachers' Algebra Definitions Before and After the Program

\begin{tabular}{lcc}
\hline The Focus of the Definition & $\begin{array}{c}\text { At the Beginning } \\
(n=26)\end{array}$ & $\begin{array}{c}\text { At the End } \\
(n=22)\end{array}$ \\
\hline Building and Solving Equations & $21(\% 81)$ & $16(\% 73)$ \\
Arithmetic Operations & $3(\% 11)$ & 0 \\
A Relationship Between Quantities & $3(\% 11)$ & $9(\% 41)$ \\
\hline
\end{tabular}

There were significant changes in the participants' definitions of algebra before and after participating in the professional development program. First, initially, three teachers defined algebra incorrectly by focusing on four operations only. An example of such a definition was as follows: "Algebra consists of problems that require using four operations." There were not any teachers who defined algebra incorrectly at the end of the program. Moreover, the definitions of algebra enriched. In addition to focusing on building and solving equations, algebra as a discipline that studies the relationship between two variables was mentioned by more teachers. For example, a teacher whose definition was coded as "a relationship between quantities" defined algebra as the following: "Expressions that describe the relationship between variables with mathematical operations." The change in the algebra definitions indicates that the participants enhanced their content knowledge, one of the TPCK knowledge domains, throughout the program.

The algebra questions written by the teachers confirmed the findings related to the development of their content knowledge. Furthermore, these questions indicated an improvement in the teachers' pedagogical content knowledge. At the beginning of the program, most of the teachers (\%81, $n=26$ ) focused on building and solving equations in their definitions and wrote example questions reflecting this definition. Only two $(7 \%, n=26)$ teachers used multiple representations in their questions. Examples representing the questions written by the teachers at the beginning of the program are given below.

Example 1: There are 25 rabbits and chickens in a coop. If in all there are 90 legs, how many rabbits are there?

Example 2: What is the value of $y$ when $x=3$ for the equation $2 x+y=5$ ?

On the other hand, the example questions written at the end of the program had more instances of representing algebra as a discipline examining the relationship between variables. These questions required students to work with more representations. Eighteen $(82 \%, n=22)$ teachers used multiple representations in their questions. Examples representing the questions written by the teachers at the end of the program are given below.

Example 1: A frog jumps $20 \mathrm{~cm}$ in each jump. To calculate the distance taken by the frog after the $12^{\text {th }}$ jump;

a) Create a table. 
b) Write an algebraic expression to show the relationship between the number of jumps and the distance traveled.

c) Create a graph of the algebraic expression.

d) Interpret the graph you have plotted.

e) Find the distance traveled after the $12^{\text {th }}$ jump.

Example 2: Model $(x+3)(2 x)$ using algebra tiles.

Three representations (table, symbols, graph) are used in the first example, and two representations (symbols and concrete materials) are used in the second example. These questions require students to translate from one representation to another, to make connections among different representations of the same situation, and to reason about the mathematical procedures. Asking these types of questions indicates an improvement in the teachers' pedagogical content knowledge.

\section{Effective Elements of the Professional Development Program}

In this section, we present the findings related to the second research question "Which elements of the professional development program were perceived by the teachers as supportive of TPCK?" The evaluation forms completed by the participants at the end of the program were used to answer the second research question. The teachers' comments $(n=26)$ about the positive and negative aspects of the program were analyzed. Table 5 presents the four themes that emerged from the analysis of the participants' opinions on the positive elements of the program for their professional growth in TPCK.

Table 5 shows that according to 17 teachers, one of the effective elements of the professional development program was that the activities could be used in their classrooms. Teachers expressing this view wrote that the activities used in the program can increase active student participation, meaningful learning, and motivation level of the students in their classes. For example, one teacher pointed out that the program activities can motivate students with the following statement: "...Also, the program gave me invaluable insights on how to grab students' attention to the lesson. I strongly want to continue attending this type of training and learn about the new information." Another teacher explained that the GeoGebra software he learned in the program could be used in geometry and analytic geometry lessons, and expressed the possible benefits of GeoGebra for meaningful learning as follows: "It can be used to add visual representations to the lesson, to allow the students to explore the concepts, and to support long-lasting learning." 
Table 5. Positive Elements of the Program According to the Participants

\begin{tabular}{lll}
\hline Theme & f & \% \\
\hline Program activities can be implemented in the classroom & 17 & $\% 65$ \\
Increased knowledge about the use of technology in teaching & 15 & $\% 58$ \\
mathematics & & \\
Learned mathematics-related technological tools and programs & 11 & $\% 42$ \\
Active and collaborative participation in the program activities & 11 & $\% 42$ \\
\hline
\end{tabular}

Fifteen teachers explained that a positive element of the program was learning about new technologies that could be used to teach mathematics. Regarding this theme, they wrote that they could use technology for teaching the concepts more meaningfully, designing homework (e.g., creating a WebQuest), allowing students to practice newly learned knowledge, and assessing students' learning. For example, one teacher wrote, "I think that it was great to learn how to create a WebQuest. It would be fun to prepare homework for students in this way and I believe that it will be beneficial for students." Another teacher made the following comment: "For the first time, we had the opportunity to work in our field during the seminar period. We were able to see clearly how we can use technology more effectively in our lessons and lesson planning."

Eleven teachers referred to the technological tools and software used in the program as one of its positive aspects. Concerning this theme, some teachers wrote that they were introduced to new technologies without referring to specific tools, while some teachers exemplified the technology that they learned. For example, one teacher wrote, "I learned the GeoGebra software, thanks to the program." while another teacher wrote, "We used a calculator that we have never seen before. We created graphs on the calculator with motion detectors."

Eleven teachers wrote that a positive aspect of the program was being able to complete the program activities in an interactive environment. The participants expressed the view that the program activities were hands-on, fun, and offered opportunities to exchange views among the teachers. For example, one of the participants wrote, "We learned by experimenting and discovering in the program activities. In other words, by doing. I did not understand how the time passed." There were also suggestions to enhance this aspect of the program. Some teachers suggested changing the group members throughout the program to create more interactions between the teachers. One teacher suggested using creative drama to help teachers get to know each other better.

In summary, four elements of the program were identified by the teachers as supportive of their TPCK. Most teachers did not write down any negative aspects of the program. Four teachers specified a 1-hour presentation as a negative element of the program. This presentation was the only time when the teachers passively listened to a speech about the 
benefits of using technology in education. These four teachers wrote that it was not effective and that teachers should be active in all program activities.

\section{DISCUSSION}

This study examined TPCK changes of middle school mathematics teachers who participated in a professional development program designed to integrate technology into teaching algebra. The data analysis revealed that the participants' TPCK levels significantly increased as a result of participating in the program. The findings of the current study are consistent with the findings of research studies that examined the effects of professional development programs or courses aimed to improve teachers' TPCK levels (Mishra \& Koehler, 2006; Niess et al., 2010; Richardson, 2009; Xie et al., 2017). The previous studies found that programs focusing on the effective use of technology in mathematics education improved teachers' TPCK levels. The current study contributes to research in this area by focusing on a single strand of mathematics, namely algebra, and on a specific grade band, grades 6-8. This design allowed the program to focus on content, pedagogy, technology, and their integration.

One of the findings of the study is that the participants enriched their algebra definitions (content knowledge). Usiskin (1988) discussed four different definitions of algebra: generalized arithmetic, the study of procedures used to solve certain types of problems, the study of relationships among quantities, and the study of structures. Some of the participating teachers defined algebra as four operations at the beginning of the program, which is more about arithmetic than algebra (Akkan et al., 2011). Most of the participants defined algebra as building and solving equations at the beginning of the program, presenting a limited definition of algebra. This definition falls within Usiskin's (1988) second notion: the study of procedures used to solve certain types of problems. At the end of the professional development program, none of the teachers defined algebra as arithmetic operations. In addition, some teachers enriched their algebra definitions by referring to "the study of relationships among quantities" notion of algebra. The enrichment of teachers' perspectives on the meaning of algebra is an important step for effective teaching (Ball et al., 2008). Teachers who have deep content knowledge can better scaffold their students' mathematical thinking.

The TPCK survey, the lesson plans designed by the participants, and the questions written to represent algebra showed improvements in the participants' TPCK. Specifically, the lesson plans indicated that the participants were able to plan lessons that demonstrated effective use of technology to teach algebra topics (TPCK). The questions written by the participants to represent algebra required students to use multiple representations and to engage in mathematical reasoning as suggested by the mathematics education communities (e.g., NCTM, 2000). The questions indicated development in the participants' pedagogical content knowledge. These are positive results for the designed professional development program.

The positive effects of the professional development program seem to depend on some elements of the program. These elements are the applicability of the program activities in the 
middle school classrooms, the program's focus on using technology in teaching algebra, the introduction of new technological tools and software related to mathematics, and the interactive nature of the program. The program content was selected according to the existing curriculum since the school curriculum is one of the core determinants of teacher motivation (Kagema, 2018). The participating teachers liked this aspect of the program as they will be able to use the program activities in their classrooms. For teachers who want to enhance their professional knowledge and practices, learning a new method or tool can be a motivational factor by revealing the areas that need improvement (Hashweh, 2003). The participants used some technological tools (for example, a motion detector) for the first time in the program. They were not only introduced to new technological tools but they also experienced how these tools can be used in the classroom to teach algebra. The program's focus on a certain content area (algebra) while introducing new technology is an element that helped teachers to develop and integrate their pedagogical, content, and technology knowledge, parallel to the recommendations of studies examining effective professional development programs (Garet et al., 2001; Mishra \& Koehler, 2006). The program's interactive learning environment allowed the teachers to reflectively assess the advantages and disadvantages of the instructional methods used in the program. Most program activities were completed as group work, and at the end of each activity, there was a whole group discussion that promoted reflection on the teaching and learning processes. Reflective thinking and collective discussion are important approaches that help teachers deeply examine new information and consolidate learning (Zaslavsky, 2007), as also observed in the current study.

\section{CONCLUSION}

Teachers need to enhance their professional knowledge and practices in order to provide positive learning environments to their students (Borasi et al., 1999). Examining professional development programs that might support teachers' professional growth is important to understand different approaches to professional development. In this study, the effects of a professional development program that focused on using technology to teach middle school algebra were examined and the positive effects of the program have been reported. Focusing on a certain content domain and grade level and using an interactive approach to training were found to be positive elements of the program. The current program was limited to examining the teachers' knowledge growth outside of their classroom. Future studies may examine the effects of such programs on teachers' practices in their classrooms. In addition, students' learning in participant teachers' classrooms might be examined to understand the benefits or limitations of similar programs.

\section{Funding Information}

This publication resulted from research supported by the Scientific and Technological Research Council of Turkey with grant number 213B766. 


\section{REFERENCES}

Aronson, B., Banda, R., Johnson, A., Kelly, M. Radina, R., Reyes, G., Sander, S., \& Wronowski, M.(2020). The social justice teaching collaborative: A critical turn towards critical teacher education. Journal of Curriculum Studies Research, 2(2), 21-39. https://doi.org/10.46303/icsr.2020.8

Akkan, Y., Baki, A., \& Çakıroğlu, Ü. (2011). Differences between arithmetic and algebra: Importance of pre-algebra. Elementary Education Online, 10(3), 812-823.

Ball, D. L., Thames, M. H., \& Phelps, G. (2008). Content knowledge for teaching: What makes it special? Journal of Teacher Education, 59(5), 389-407.

Borasi, R., Fonzi, J., Smith, C. F., \& Rose, B. J. (1999). Beginning the process of rethinking mathematics instruction: A professional development program. Journal of Mathematics Teacher Education, 2(1), 49-78.

Boston, M. D. (2013). Connecting changes in secondary mathematics teachers' knowledge to their experiences in a professional development workshop. Journal of Mathematics Teacher Education, 16(1), 7-31.

Bozkurt, A., \& Cilavdaroğlu, A. K. (2011). Mathematics and classroom teachers' perceptions of technology use and integration into their instruction. Kastamonu Education Journal, 19(3), 859-870.

Bray, A., \& Tangney, B. (2017). Technology usage in mathematics education research-A systematic review of recent trends. Computers \& Education, 114, 255-273.

Drijvers, P., Ball, L., Barzel, B., Heid, M. K., Cao, Y., \& Maschietto, M. (2016). Uses of technology in lower secondary mathematics education: A concise topical survey. Springer Nature. https://link.springer.com/content/pdf/10.1007\%2F978-3-319-33666-4.pdf

Etherington, M. (2019). The challenge with educational transformation. Journal of Culture and Values in Education, 2(1), 96-112. https://doi.org/10.46303/jcve.02.01.8

Fernandez, M. L. (2001). Graphical transformations and calculator greeting cards. The Mathematics Teacher, 94(2), 106-111.

Garet, M., Porter, A., Desimone, L. Birman, B., \& Yoon, K. (2001). What makes professional development effective? Results from a national sample of teachers. American Education Research Journal, 38(4), 915-945.

Graham, C., Tripp, T., \& Wentworth, N. (2007). Using preservice teacher work samples as a means for assessing and improving technology integration in field experiences. Technology and Teacher Education Annual, 18(3), 1263-1268.

Gürbüz, S., \& Şahin, F. (2015). Sosyal bilimlerde araştırma yöntemleri: Felsefe-yöntem-analiz (2. baskı) [Research methods in social sciences: Philosophy-method-analysis ( $2^{\text {nd }}$ edition)]. Seçkin Publishing.

Hashweh, M. Z. (2003). Teacher accommodative change. Teaching and Teacher Education, 19, 421-434. 
Hohenwarter, M. (2002). GeoGebra - ein Softwaresystem für dynamische Geometrie und Algebra der Ebene [GeoGebra - a software system for dynamic geometry and algebra in the plane] (Unpublished master's thesis). University of Salzburg.

Hove, B., \& Dube, B. (2021). Covid-19 and the entrenchment of a virtual Elite private school: Rethinking education policies in Zimbabwe. Journal of Culture and Values in Education, 4(2), 84-94. https://doi.org/10.46303/jcve.2021.5

Kagema, J. (2018). The school curriculum and its influence on teacher motivation in curriculum implementation in Kenya. Journal of Culture and Values in Education, 1(1), 9-25. https://doi.org/10.46303/jcve.01.01.2

Kastberg, S., \& Leatham, K. (2005). Research on graphing calculators at the secondary level: Implications for mathematics teacher education. Contemporary Issues in Technology and Teacher Education, 5(1), 25-37.

Katz, V. (2007). Algebra: Gateway to a technological future. Mathematical Association of America.

Li, Q., \& Ma, X. (2010). A meta-analysis of the effects of computer technology on school students' mathematics learning. Educational Psychology Review, 22(3), 215-243.

Lincoln, Y. S., \& Guba, E. G. (1985). Naturalistic inquiry. Sage Publications.

Loucks-Horsley, S., Stiles, K. E., Mundry, S., Hewson, P. W., \& Love, N. (2010). Designing professional development for teachers of science and mathematics (3rd ed.). Corwin Press.

Martin, W., Strother, S., Beglau, M., Bates, L., Reitzes, T., \& McMillan Culp, K. (2010). Connecting instructional technology professional development to teacher and student outcomes. Journal of Research on Technology in Education,43(1), 53-74.

Ministry of National Education. (2009). Ilköğretim matematik dersi (6-8. sınıflar) öğretim programı ve klavuzu [Middle school (6-8) mathematics curriculum and guide]. Talim Terbiye Kurulu Başkanlığı.

Ministry of National Education. (2018). Matematik dersi öğretim program [Mathematics curriculum] (Online). https://mufredat.meb.gov.tr/

Mishra, P., \& Koehler, M. J. (2006). Technological pedagogical content knowledge: A framework for teacher knowledge. Teachers College Record, 108(6), 1017-1054.

National Council of Teachers of Mathematics. (2000). Principles and standards for school mathematics. Author.

Niess, M. L. (2005). Preparing teachers to teach science and mathematics with technology: Developing a technology pedagogical content knowledge. Teaching and Teacher Education, 21(5), 509-523.

Niess, M. L.,vanZee, E. H., \& Gillow-Wiles, H. (2010). Knowledge growth in teaching mathematics/science with spreadsheets: Moving PCK to TPACK through online professional development. Journal of Digital Learning in Teacher Education, 27(2), 42-52. 
Önal, N., \& Çakır, H. (2016). Middle school mathematics teachers' views on using information technology in mathematics education. Mersin University Journal of the Faculty of Education, 12(1), 76-94. https://dergipark.org.tr/en/download/article-file/161102

Öztürk, E., \& Horzum, M.B. (2011). Teknolojik pedagojik içerik bilgisi ölçeği'nin Türkçeye uyarlaması [Adaptation of technological pedagogical content knowledge scale to Turkish]. Ahi Evran Üniversitesi Eğitim Fakültesi Dergisi, 12(3), 255-278.

Patton, M. Q. (2002). Qualitative research \& evaluation methods ( $3^{\text {rd }}$ ed.). Sage Publications.

Pozdniakov, S., \& Freiman, V. (2021). Technology-supported innovations in mathematics education during the last 30 years: Russian perspective. ZDM Mathematics Education, 53, 1499-1513. https://doi.org/10.1007/s11858-021-01279-6

Raines, J. M., \& Clark, L. M. (2011). A brief overview on using technology to engage students in mathematics. Current Issues in Education, 14(2), 1-7. http://cie.asu.edu/ojs/index.php/cieatasu/article/view/786

Richardson, S. (2009). Mathematics teachers' development, exploration, and advancement of technological pedagogical content knowledge in the teaching and learning of algebra. Contemporary Issues in Technology and Teacher Education [Online serial], 9(2), 117-130. http://www.citejournal.org/vol9/iss2/mathematics/article1.cfm

Rodríguez-Muñiz, L. J., Burón, D., Aguilar-González, Á., \& Muñiz-Rodríguez, L. (2021). Secondary mathematics teachers' perception of their readiness for emergency remote teaching during the COVID-19 pandemic: A case study. Education Sciences, 11(5), 228.

Roschelle, J. M., Pea, R. D., Hoadley, C. M., Gordin, D. N., \& Means, B. M. (2000). Changing how and what children learn in school with computer-based technologies. The Future of Children, 10(2), 76-101.

Schmidt, D. A., Baran, E., Thompson, A. D., Mishra, P., Koehler, M. J., \& Shin, T. S. (2009). Technological pedagogical content knowledge (TPACK): The development and validation of an assessment instrument for preservice teachers. Journal of Research on Technology in Education, 42(2), 123-149.

Souter, M. T. (2001). Integrating technology into the mathematics classroom: An action research study. Action Research Exchange, 1(1), 1-11.

Strauss, A., \& Corbin, J. (1990). Basics of qualitative research: Grounded theory procedures and techniques. Sage Publications.

Subedi, D., \& Subedi, R. (2020). Practicing self learning of ICT for resilience amidst the COVID-19 outbreak: Experiences from Kathmandu Valley. Research in Educational Policy and Management, 2(2), 78-96. https://doi.org/10.46303/repam.2020.5

Tong, D. H., Uyen, B. P., Kieu, H. T. D., \& Ngan, L. K. (2021). The effectiveness of using GeoGebra software in mathematics classrooms: A case study of teaching continuous functions in high schools. Journal of Hunan University Natural Sciences, 48(9), 256-268. 
Usiskin, Z. (1988). Conceptions of school algebra and uses of variable. In A. F. Coxford \& A. P. Shulte (Eds.), The ideas of algebra, K-12 (1988 Yearbook of the National Council of Teachers of Mathematics, pp. 8-19). NCTM.

Wentworth, N., \& Monroe, E. E. (2011). Inquiry-based lessons that integrate technology: Their development and evaluation in elementary mathematics teacher education. Computers in the Schools, 28, 263-277.

Xie, K., Kim, M. K., Cheng, S. L., \& Luthy, N. C. (2017). Teacher professional development through digital content evaluation. Educational Technology Research and Development, 65(4), 1067-1103.

Yoon, K. S., Duncan, T., Lee, S. W. Y., Scarloss, B., \& Shapley, K. (2007). Reviewing the evidence on how teacher professional development affects student achievement (Issues and Answers Report, REL 2007 No. 033). U.S. Department of Education, Regional Educational Laboratory Southwest.

Zaslavsky, O. (2007). Mathematics-related tasks, teacher education, and teacher educators. Journal of Mathematics Teacher Education, 10(4-6), 433-440. 